International Journal of English Language Studies (IJELS)

ISSN: $2707-7578$

DOI: $10.32996 /$ ijels

Website: https://al-kindipublisher.com/index.php/ijels

\title{
An Analysis of Mitigating Devices of Request Used by Saudi EFL Learners
}

\author{
Fadi Maher Al Khasawneh \\ Department of English Language, Faculty of Languages and Translation, King Khalid University, Abha, Saudi Arabia
}

$\square$ Corresponding Author: Fadi Maher Al Khasawneh, E-mail: fadialkhasoneh@kku.edu.sa

\begin{abstract}
ARTICLE INFORMATION
Received: 22 October 2021

Accepted: 15 November 2021

Published: 27 November 2021

DOI: 10.32996/ijels.2021.3.11.7

\section{KEYWORDS}

Mitigation, mitigating devices, Speech act of requests, pragmatics, Saudi EFL learners

\section{ABSTRACT}

This study aimed at exploring the linguistic mitigating devices of requests used by Saudi EFL learners. The participants of this study were 97 students enrolled in the English program at King Khalid University, Saudi Arabia. The data of this study were collected by Discourse Completion Test (DCT) questionnaire designed for the purpose of this study. The questionnaire contained five different situations of request and the factor of Social Distance (SD) was incorporated to investigate any differences of the learners' request strategies attributed to this factor. The data were classified according to the Cross-Cultural Study of Speech Act Realization Patterns (CCSARP) by Blum-Kulka and Olshtain (1984). The findings of this study revealed that the participants preferred to use internal mitigating devices more frequently than external ones. They also were more direct when making requests and it seems that social distance does not play a significant role in the students' modification strategies of requests.
\end{abstract}

\section{Introduction}

Pragmatic competence has long been seen as the effective use of language to achieve a specific purpose and to understand language in context (Thomas, 1983) She breaks down pragmatic competence to pragma-linguistic competence, which refers to the use of proper language to recognize a certain speech act. The other component is socio-pragmatic competence, which refers to the appropriate use of speech act in the appropriate context (Thomas, 1983). Numerous studies have acknowledged the importance of pragmatic competence (Al-Ali \& Alawneh, 2010; Cohen, 1996; Uso- Juan \& Martinez-Flor, 2007). These studies have demonstrated the crucial role of appropriate speech acts for competent interaction. Pragmatic errors may be negatively interpreted, leading the addressee to assign a wrong interpretation to a certain utterance (Nelson et. al., 2002). Hence proved, appropriate communication requires sufficient knowledge of speech acts, discourse, and the functional units of communicative language such as apologizing, threatening, complimenting, and requesting (Cohen, 1996).

Requests, the focus of this study, are speech acts in which the speaker attempts to get the hearer to perform an action. According to Searle (1979), requests could be classified into direct and indirect requests. Direct requests occur when the real intention of the speaker's request (illocutionary force) conforms to the literal meaning of the speaker's utterance (locutionary force). For example, the utterance 'close the window' has the same intention as its literal meaning. On the other hand, indirect requests occur when the illocutionary force is different from the locutionary force of the request utterance (Searle, 1979). For example, the utterance 'it is cold in here' could be used to get the hearer to switch on a heater. The use of direct and indirect requests is constrained by various factors such as gender, educational background, age, social power, and social distance. The speaker may prefer to use either direct or indirect requests based on the previously mentioned factors to produce a polite request (Aldhulaee, 2011).

The question of how to soften and mitigate requests has long been discussed. Mitigation is used to avoid the unwelcomed effect of the request being asked (Ali \& Salih, 2020). Mitigating devices play a vital role in social function. They are considered as strategic means for reducing or softening face-threatening that may arise in interlocution (Fraser, 1980). These devices form an integral component of the pragmatic competence for language learners who encounter difficulties in the principles of pragmatic of the target language. The previous literature on the speech act of requests has revealed different conclusions. First, learners of the target language may use various degrees of directness and indirectness in their requests to reflect politeness. Second, requests might be affected by the norms of the native language to the target language. Third, mitigating devices are used based on the

Copyright: (c) 2021 the Author(s). This article is an open access article distributed under the terms and conditions of the Creative Commons Attribution (CC-BY) 4.0 license (https://creativecommons.org/licenses/by/4.0/). Published by Al-Kindi Centre for Research and Development, London, United Kingdom. 
situational factors involved. The previous literature has also revealed very few studies that have investigated the use of mitigating devices of requests among Saudi EFL learners. Therefore, the present study aims at seeking answers for the following research questions:

1. What are the mitigating devices of requests used by Saudi EFL learners?

2. How does the aspect of social distance affect the use of mitigating devices?

\section{Literature Review \\ 2.1 Speech Acts}

Speech act involves three different facets: locutionary (describes what someone says), illocutionary (describes what speakers intend to say), and perlocutionary act (the resulting action of the illocutionary force of an utterance (Yazdanfar \& Bonyadi, 2016). According to Searle (1975), illocutionary acts can be classified into six types: 1) Representative: to describe the situation (asserting, stating, confessing), 2) Directive: to have somebody do something (ordering, warning, forbidding, requesting), 3) Question: to get information from somebody (inquiring, asking), 4) Commissive: to commit the speaker to do something (pledging, vowing, promising), 5) Expressive: to express emotions (congratulating, thanking, apologizing), 6) Declaration: changing the status of some entities (resigning, appointing, naming).

\subsection{Direct and Indirect Illocutionary Act}

Illocutionary acts would directly be stated when the syntactic form of the utterance matches its illocutionary force. Each type of sentence is linked with a specific illocutionary act. For instance, an expressive speech act is in fact delivered directly when it is followed by the exclamation, or requests by an imperative (Yazdanfar \& Bonyadi, 2016). Requests can be considered or rude or impolite when using a direct speech act. To avoid impoliteness, speakers tend to soften or mitigate the effect of speech acts, they tend to speak indirectly by using some syntactic forms, which reduce the illocutionary imposition of the utterance (Parker $\&$ Riley, 1994). Thomas (1983) points out that speakers tend to use indirect requests to have more fascinating speech, to be different in their attempts to reach goals or to decorate the communicated message. Hence, the high level of politeness is associated with a high level of indirectness.

\subsection{Politeness Theory}

The concept of politeness is concerned with the comfort of others and not hurting their sensations. Goffman (1967) views politeness as the conception shown by individuals through avoidance or evasion. Politeness is very important to avoid struggles during a conversation between the speakers and the hearer, and this could be achieved through using indirect speech acts. Brown and Levinson (1978) indicate that people show politeness using indirect strategies over direct ones. In a similar vein, Leech (1983) argues that politeness degree could be boosted using indirect strategies because it increases optionality and diminishes the imposition of speech acts. Goffman (1967) proposed the idea of the face-threatening act, which he defined as a changeable mask that depends on the social interaction and audience. The idea of the face can vary according to social circumstances and cultures. Speakers wish to maintain their image when they communicate with others. Face can be maintained, lost, or augmented and must continuously be attended to in conversations (Goffman, 2006, pp. 299, 310).

Brown and Levinson (1978) define the face as the need to act without imposition as the goal is to maintain a positive face admired by the audience. They added that face-threatening acts refer to acts such as abasement or contempt, which defy the positive face of speakers. According to Brown and Levinson, politeness has two kinds: positive and negative politeness. Positive politeness would save the hearer's face, and which indicates tenacity with the participants. Some strategies could be used to show positive politeness, such as slang, informal pronunciation, and indirect requests. On the other hand, negative politeness saves the negative face of hearers, and it displays reverence to others' concerns and wants. The negative politeness strategies may implicate indirect and impersonal requests and mitigations. Mitigating devices are used to soften the impact of requests and/or utterances, especially when having a social distance between interlocutors (Yazdanfar \& Bonyadi, 2016).

\subsection{Mitigating Devices}

Speakers tend to use some strategies to soften the effect of requests using internal or external mitigating devices whose function is to mitigate the request. Blum-Kulka and Olshtain (1984) state that linguistic mitigating devices could be classified into internal mitigating devices that appear as head act and supportive moves, which can be either to mitigate (downgraders), or to enhance (upgraders) the illocutionary force of the request. Downgraders are classified into syntactic downgraders and lexical downgraders. Examples of syntactic downgraders may include the following:

- Interrogative: "Could you pass the salt to me?"

- $\quad$ Negation: "If you could please not park your car here, we would be grateful."

- $\quad$ Past Tense: "I wanted to request another chance."

- Embedded "if" clause: "I would appreciate it if you can help me." 
Lexical downgraders may include the following:

- Consultative: "Do you think I can obtain the results of the analysis."

- Understaters: "Could you do a quick check before we begin?"

- Hedges: "It would be wonderful if we did something for that girl."

- Downtoners: "Perhaps you will be able to fetch me from school."

The upgraders devices include the following:

- Intensifiers: "Clean up your room, it is horrible."

- Expletives: "You still haven't cleaned the bloody mess in your room!"

On the other hand, external mitigating devices are optional clauses that appear in the immediate context of the speech act. BlumKulka and Olshtain (1984) proposed some categories of external mitigating devices as follows:

- $\quad$ Checking on availability: for example, are you going to the kitchen? if so, is it ok if you bring the salt with you?

- Getting a pre-commitment: for example, "Will you help me? Could you perhaps lend me your notebook?

- Grounder: for example, Mark, I did not attend yesterday's class, can I get your notebook?

- Sweetener: for example, you are the best student in class, would you lend me your notes for a couple of hours?

- Disarmer: for example, pardon me, I hope I am not bothering you at this time, but is it possible to send the report to my email?

- Cost minimizer: for example, excuse me, but could you give me a ride? if you are going in my direction, as my car broke down and I will have my exam in 45 minutes

\subsection{Previous Studies}

Several studies (Al-Ali \& Alawneh, 2010; Aldhulaee, 2011; Nugroho \& Rekha, 2020; Yazdanfar \& Bonyadi, 2016) have been conducted to investigate request strategies and mitigating devices used by learners. Al-Ali and Alawneh (2010) examined the mitigating devices of requests used by Jordanian EFL learners and native American speakers of English. The total number of participants in this study was 90 undergraduate students selected from Jordanian and American universities. The data of this study have been collected through a specially designed Discourse Completion Test (DCT) with six situations of requests. The findings of this study revealed significant differences between Jordanian and American participants in the structure, type, and frequency of the utilized requests. The study also found three major factors that influenced the request choice of Jordanian participants: L1 pragmatic knowledge, transfer of L1 cultural norms, and language proficiency. Aldhulaee (2011) studied the mitigating devices used by Australian English native speakers of English and Iraqi Arabic native speakers to soften the force of requests in daily situations. The data of this study have been collected through role-play interviews between both Australians and Iraqis, and the mitigating devices used by the participants have been identified and classified. The findings of this study revealed that internal mitigating devices were more frequent in the requests of Australian participants than Iraqi participants, while the use of external mitigating devices was common in both groups. In addition, the two groups used some mitigating devices with different semantic formulae in some situations. The variance in the use of requests between both groups is attributed to different factors: language proficiency, linguistic, and cultural variation.

Nugroho and Rekha (2020) studied the speech act of requests utilized by Indonesian EFL learners and the reasons for such usage. The sample of this study included (40) Indonesian EFL learners who enrolled in the University of Surakarta, Indonesia. The researchers used three means of data collection: the DCT questionnaire, focus group discussion, and role play. The data of this study were analyzed according to Blum-Kulka and Olshtain's (1984) Cross-Cultural Study of Speech Act Realization Pattern (CCSARP), and by transcribing the results of focus group discussion. The findings of this study showed that Indonesian EFL learners used indirect request strategies more frequently than other strategies. The frequent use of indirect strategies was attributed to cultural factors and the social distance between the interlocutors. Yazdanfar and Bonyadi (2016) explored the speech act of requests used by English and Persian speakers based on supportive moves and level of directness. To achieve this purpose, Persian and English TV series were spotted, and the utterances of requests were transcribed. The requests were classified based on Blum-Kulka and Olshtain's (1984) Cross-Cultural Study of Speech Act Realization Pattern (CCSARP) for mitigating devices and directness. The findings illustrated that direct strategy of requests was used more frequently than other strategies. Nonetheless, native speakers of English utilized more indirect strategies than native speakers of Persian. Moreover, English speakers used more linguistic mitigating devices than Persian speakers in their conversations with family members and friends. 


\section{Methodology}

\subsection{Participants}

The participants of the present study included ninety-seven Saudi undergraduate students (60 male and 37 female) majoring in English at King Khalid University, Saudi Arabia. The age of the participants ranged between 20-22 years old. The selected participants were seniors and graduate students. This is to ensure a level of proficiency that allows them to participate. These students are assumed to have adequate language proficiency as they have previously received formal schooling and are able to understand and interact with the situations in the DCT questionnaire.

\subsection{Data Collection and Analysis}

The data of this study were collected by Discourse Completion Test (DCT) questionnaire. This kind of questionnaire was first introduced by Blum-Kulka (1984) to compare patterns of speech acts between native and non-native speakers of English. Cohen and Olshtain (1981) point out that DCT is an effective means of gathering data on speech acts within and across language groups. The DCT questionnaire of this study contained five situations, each situation was followed by a blank space where the students were asked to provide their requests based on the given situations. The factor of social distance (SD) was taken into consideration during the formulation of the involved DCT (table 1). A concise description was included in each situation to clarify the relationship between the interlocutors. The obtained data from the DCT questionnaire were identified, classified, coded, and inserted into SPSS analysis software (version 26) to see the most frequently used mitigating devices. The data were classified according to the CrossCultural Study of Speech Act Realization Patterns (CCSARP) by Blum-Kulka and Olshtain (1984).

Table 1: The Distribution of the Situations According to Social Distance Factor

\begin{tabular}{|l|l|}
\hline Situation & Social Distance \\
\hline Asking for a recommendation letter & - SD \\
\hline Request to borrow a book from a professor & + SD \\
\hline Asking a stranger for a ride & + SD \\
\hline Request to borrow a notebook from a classmate & - SD \\
\hline Asking for a sheet of paper & + SD \\
\hline
\end{tabular}

\section{Results and Discussion}

\subsection{What are the mitigating devices of requests used by Saudi EFL learners?}

This section presents the obtained results to answer the first research question. Table (2) below illustrates the mitigating devices of requests used by Saudi EFL learners.

Table 2: Frequency of Mitigating Devices Used by Saudi EFL Learners

\begin{tabular}{|l|l|l|}
\hline Internal Mitigations & Occurrences & Percentage \\
\hline Device & $\mathbf{6 0}$ & $\mathbf{6 1 . 8 5}$ \\
\hline Syntactic Downgraders & 29 & 29.89 \\
\hline Interrogative & 23 & 23.71 \\
\hline Mixed & 4 & 4.12 \\
\hline Past Tense & 4 & 4.12 \\
\hline Embedded "if" clause & 0 & 0 \\
\hline Negation & $\mathbf{1 2}$ & $\mathbf{1 2 . 3 7}$ \\
\hline Lexical Downgraders & 3 & 3.09 \\
\hline Hedges & 3 & 3.09 \\
\hline Downtoners & 3 & 3.09 \\
\hline Politeness marker & 2 & 2.06 \\
\hline Understaters & 1 & 1.03 \\
\hline Consultative & $\mathbf{0}$ & $\mathbf{0}$ \\
\hline Upgraders & 0 & 0 \\
\hline Intensifiers & 0 & 0 \\
\hline Expletives & $\mathbf{7 2}$ & $\mathbf{7 4 . 2 2}$ \\
\hline Total & \multicolumn{2}{|l}{} \\
\hline External Mitigations & $\mathbf{O c c u r r e n c e s}$ & Percentage \\
\hline Device & 10 & 10.30 \\
\hline Grounder & 8 & 8.24 \\
\hline Getting a pre-commitment & \multicolumn{2}{|l|}{} \\
\hline
\end{tabular}




\begin{tabular}{|l|l|l|}
\hline Checking on availability & 4 & 4.12 \\
\hline Sweetener & 3 & 3.09 \\
\hline Disarmer & 0 & 0 \\
\hline Cost minimizer & 0 & 0 \\
\hline Total & $\mathbf{2 5}$ & $\mathbf{2 5 . 7 7}$ \\
\hline
\end{tabular}

Table (2) illustrates that Saudi EFL learners used internal mitigations much more than external ones, with 72 occurrences (74.22\%). The participants used syntactic downgraders 60 times (61.85\%), lexical downgraders 12 (12.37\%), and no occurrences were found for upgraders (0\%). The most frequently mitigating device used by the participants was interrogative with 26 occurrences (26.80\%). Examples of this device are as follows:

Will you write a recommendation letter for me?

(Situation 1)

Can you help me get there on time?

(Situation 3)

Many of the participants, 23 (23.71\%), preferred to use mixed mitigating devices of requests. Below are some examples of mixed mitigating devices.

Can you possibly take me there? (Interrogative and Downtoner)

(Situation 3)

I wonder if you can drive me to my college. (Embedded if clause and Hedge)

(Situation 3)

Perhaps, you can do me a favor, I need some sheets of paper. (Interrogative, downtoner, and pre-commitment) (Situation 5)

Past tense and embedded "if" clause devices have been used four times (for each), by the participants. The examples for each device are offered below:

I just want to ask if I can borrow your notebook for a couple of minutes. (Embedded if clause)

(Situation 4)

I was wondering whether you could lend me the book as a reference for my paper. (Past Tense)

(Situation 2)

In addition, the students used lexical downgraders in 12 occurrences (12.37\%). Hedges, downtoners, and politeness markers appeared in 3 occurrences (3.09\%) for each, followed by understaters 2 (2.06\%), and consultative 1 (1.03\%). No occurrences have been reported to upgrader mitigations. Consider the following extracts:

I would much appreciate it if I can get the book for a couple of days. (Hedge)

(Situation 2)

Is it possible to give me some papers? (Downtoner)

(Situation 5)

Could you please help me with the recommendation letter? (Politeness marker)

(Situation 1)

Can I borrow your notebook for a little while? (Understater)

(Situation 4)

Do you think I am eligible enough to get your recommendation for the scholarship? (Consultative)

(Situation 1) 
On the other hand, the students used external mitigations but with less frequency than internal ones. The most frequent external mitigation was grounder with 10 occurrences (10.30\%), followed by getting a pre-commitment 8 (8.24\%), checking on availability 4 $(4.12 \%)$, sweetener $3(3.09 \%)$, and no occurrences have been reported to disarmer and cost-minimizer mitigations. Examples of external mitigations are as follows:

I wonder if you can drive me to my college. You see, I have an exam after half an hour and the bus broke down, so I am in big trouble over here. (grounder)

(Situation 3)

May I ask for a favor? Could I borrow your notebook? (Pre-commitment)

(Situation 4)

Could you please drive me to the college if it is on your way? (Check on Availability)

(Situation 3)

Can I borrow your notebook? I know you are the best student in the class. (Sweetener)

(Situation 4)

\subsection{How does the aspect of social distance affect the use of mitigating devices?}

As mentioned earlier, the present study used a DCT questionnaire to collect the data. The aspect of social distance has been considered in that questionnaire. The results obtained to answer this research question are presented in table (3).

Table 3: The Use of Mitigating Devices in Relation to Social Distance

\begin{tabular}{|c|c|c|c|c|c|c|c|}
\hline \multirow{2}{*}{\begin{tabular}{|l|} 
Internal Mitigations \\
Syntactic Downgraders \\
\end{tabular}} & \multicolumn{7}{|c|}{ Situation } \\
\hline & S1 & S2 & S3 & S4 & S5 & \begin{tabular}{|l|} 
Total \\
\end{tabular} & Percentage \\
\hline Interrogative & 4 & 5 & 5 & 7 & 8 & 29 & 29.89 \\
\hline Mixed & 2 & 4 & 6 & 4 & 7 & 23 & 23.71 \\
\hline Past Tense & 1 & 0 & 1 & 2 & 0 & 4 & 4.12 \\
\hline Embedded "if" clause & 1 & 1 & 0 & 2 & 0 & 4 & 4.12 \\
\hline Negation & 0 & 0 & 0 & 0 & 0 & 0 & 0 \\
\hline Lexical Downgraders & S1 & S2 & S3 & S4 & S5 & Total & Percentage \\
\hline Hedges & 0 & 1 & 1 & 1 & 0 & 3 & 3.09 \\
\hline Downtoners & 1 & 0 & 0 & 1 & 1 & 3 & 3.09 \\
\hline Politeness marker & 1 & 1 & 1 & 0 & 0 & 3 & 3.09 \\
\hline Understaters & 0 & 1 & 0 & 1 & 0 & 2 & 2.06 \\
\hline Consultative & 1 & 0 & 0 & 0 & 0 & 1 & 1.03 \\
\hline Upgraders & S1 & S2 & S3 & S4 & S5 & Total & Percentage \\
\hline Intensifiers & 0 & 0 & 0 & 0 & 0 & 0 & 0 \\
\hline Expletives & 0 & 0 & 0 & 0 & 0 & 0 & 0 \\
\hline External Mitigations & S1 & S2 & S3 & S4 & S5 & Total & Percentage \\
\hline Grounder & 2 & 2 & 3 & 2 & 1 & 10 & 10.30 \\
\hline Getting a pre-commitment & 0 & 2 & 1 & 3 & 2 & 8 & 8.24 \\
\hline Checking on availability & 1 & 0 & 2 & 1 & 0 & 4 & 4.12 \\
\hline Sweetener & 0 & 0 & 0 & 2 & 1 & 3 & 3.09 \\
\hline Disarmer & 0 & 0 & 0 & 0 & 0 & 0 & 0 \\
\hline Cost minimizer & 0 & 0 & 0 & 0 & 0 & 0 & 0 \\
\hline
\end{tabular}

As illustrated in table (3), interrogative mitigations were more frequent in the situation (5), followed by the situation (4), situations (2), and (3), while situation (1) reported the least frequent occurrences of interrogative mitigations. The mixed mitigating devices were used in the situation (5) more frequently compared to other situations. Situation (3) reported a considerable number of this device, followed by situations (2) and (4), and finally situation (1) with only two occurrences. Past tense mitigations occurred twice in situations (4) and once in situations (1) and (3). The embedded "if" clause was used twice in the situation (4) and once in situations (1) and (2). Regarding lexical downgraders, the participants used hedges once in three situations (2), (3), and (4), while downtoners occurred once in situations (1), (4), and (5). Politeness markers were reported once in situations (1), (2), and (3). Two understater devices were reported in situations (2) and (4) with one occurrence for each situation. The use of external mitigations was less 
frequent than internal mitigations, the participants used grounder on three occasions in the situation (3), two occasions in situations (1), (2), and (4), while it was reported once in the situation (5). Getting a pre-commitment was reported in the situation (4) with 3 occurrences, two occurrences in situations (2) and (5) for each, one occurrence in the situation (3), and it was not used in the situation (1). The use of 'checking on availability mitigation' was reported on four occasions, situation (3) with two occurrences, one occurrence in the situation (1) and (4), and no use in the situation (2) and (5). The use of sweetener has been reported three times, in the situation (4) and (5), while no occurrences were reported for disarmer and cost minimizer mitigations.

The results of this study showed that Saudi EFL learners used internal mitigating devices more than external ones. This coincides with the results of Yazdanfar and Bonyadi's (2016) study, which revealed that Persian speakers tend to use more direct request strategies than their American counterparts. It was also found that Saudi EFL learners preferred to use direct strategies more than indirect ones. This result is in contrast with the findings of Nugrobo and Rekha (2020), which showed that Indonesian EFL learners used indirect request strategies more frequently than direct strategies. According to the theory of politeness theory (Brown and Levinson (1978), the frequent use of direct strategies cannot be a clue that speakers are impolite. Blum-Kulka (1987) reexamined the concepts of indirectness and politeness and found that they are not necessarily parallel dimensions and seem to be different from each other.

Eslamirasekh (1993) argues that the implied social meaning should be taken into consideration when interpreting a linguistic behavior. He pointed out that although indirectness and politeness are connected, the members of different cultures could have different interpretations of what is direct and what is indirect. The use of verbal strategies shows negative politeness and difference through avoiding imposition. On the other hand, positive politeness achieves solidarity with the audience by using more direct strategies. Based on this argument, this study anticipates the reason for the frequent use of internal mitigating and direct strategies by Saudi EFL learners. Most of the requests made by the participants of this study are directed to friends and family with whom they do not feel the necessity to mitigate their requests as they do with people they do not know.

\section{Conclusion}

The findings of this study showed that Saudi EFL learners used internal mitigating devices more frequently than external ones. They also used direct request strategies more than indirect strategies. These findings contribute to promoting the pragmatic knowledge of EFL learners to be communicatively competent. The findings of this study would give more insights into the body of literature on this research field about the pragmatic knowledge and request strategies employed by non-native speakers of English. However, the context of this study could not generalize the pragmatic knowledge and competence of Saudi EFL learners. The generalization of the results needs recruiting a bigger number of samples and from different geographical areas of the country. Further research interested in the principles of different pragmatic strategies would make use of the results of this study. Curriculum designers would get benefits from the results of this study as well. They could consider teaching pragmatic by incorporating a specific course designed for this purpose to increase the awareness of how to use language in context and how to be more authentic in those contexts.

Acknowledgment: The authors extend their appreciation to the Deanship of Scientific Research at King Khalid University for funding this work through Big Research Groups under grant number (RGP.2 /103/42).

Conflicts of Interest: The author declares no conflict of interest.

\section{References}

[1] Al-Ali, M. N., \& Alawneh, R. (2010). Linguistic mitigating devices in American and Jordanian students' requests. Intercultural Pragmatics, 7(2). https://doi.org/10.1515/iprg.2010.014

[2] Ali, A. I., \& Salih, S. M. (2020). Taxonomy of Mitigation Devices in the English Language. Koya University Journal of Humanities and Social Sciences, 3(1), 31-40. https://doi.org/10.14500/kujhss.v3n1y2020.pp31-40

[3] Aldhulaee, M. (2011). Request mitigating devices in Australian English and Iraqi Arabic: A comparative study (Doctoral dissertation, Deakin University). https://dro.deakin.edu.au/eserv/DU:30052041/aldhulaee-requestmitigating-2011.pdf

[4] Blum-Kulka, S., \& Olshtain, E. (1984). Requests and Apologies: A Cross-Cultural Study of Speech Act Realization Patterns (CCSARP)1. Applied Linguistics, 5(3), 196-213. https://doi.org/10.1093/applin/5.3.196

[5] Blum-Kulka, S. (1987). Indirectness and politeness in requests: Same or different? Journal of Pragmatics, 11(2), 131-146. https://doi.org/10.1016/0378-2166(87) 90192-5

[6] Brown, P., \& Levinson, S. C. (1978). Universals in language usage: Politeness phenomena. In E. N. Goody (Ed.), Questions and politeness: Strategies in social interaction (pp. 256-289). Cambridge, UK: Cambridge University Press.

[7] Cohen, A. (1996). Speech acts. In Sandra McKay \& Nancy Hornberger (eds.), Sociolinguistics and language teaching, 383-420. New York: Cambridge University Press. https://eric.ed.gov/?q=John+AND+Kay\&pg=7\&id=ED411678

[8] Cohen, A. D., \& Olshtain, E. (1981). Developing a Measure of Sociocultural Competence: The Case of Apology. Language Learning, 37(1), 113-134. https://doi.org/10.1111/j.1467-1770.1981.tb01375.

[9] Eslamirasekh, Z. (1993). A cross-cultural comparison of requestive speech act realization patterns in Persian and American English. Pragmatics and Language Learning Monograph Series, 4, 85-103.

[10] Fraser, B. (1980). Conversational mitigation. Journal of Pragmatics, 4(4), 341-350. https://doi.org/10.1016/0378-2166(80)90029-6 
[11] Goffman, E. (1967). International ritual: essays on face-to-face behavior. New York: Double Day Anchor Books. https://www.worldcat.org/title/interaction-ritual-essays-on-face-to-face-behavior/oclc/550570

[12] Goffman, E. (2006). On facework: An analysis of ritual elements in social interaction. In A. Jaworski \& N. Coupland (Eds.), The discourse reader (pp. 299-310). New York, NY: Routledge.

[13] Leech, G. (1983). Principles of politeness. London, England: Longman.

[14] Nelson, G. L. (2002). Cross-Cultural Pragmatics: Strategy Use in Egyptian Arabic and American English Refusals. Applied Linguistics, 23(2), 163-189. https://doi.org/10.1093/applin/23.2.163

[15] Nugroho, A., \& Rekha, A. (2020). Speech acts of requests: A case of Indonesian EFL learners. Journal of English Language Teaching and Linguistics, 5(1), 1-16. https://jeltl.org/index.php/jeltl/article/view/371/pdf

[16] Searle, J. R., \& Searle, J. R. (1969). Speech acts An essay in the philosophy of language (Vol. 626). Cambridge university press. https://doi.org/10.1017/CBO9781139173438

[17] Searle, J. R. (1975). A taxonomy of illocutionary acts. In K. Gunderson (Ed.), Language, mind, and knowledge (pp. 344- 369). Minneapolis: University of Minnesota Press. https://conservancy.umn.edu/handle/11299/185220

[18] Thomas, J. (1983). Cross-Cultural Pragmatic Failure. Applied Linguistics, 4(2), 91-112. https://doi.org/10.1093/applin/4.2.91

[19] Uso-Juan, E., \& Martinez-Flor, A. (2007). Teaching learners to appropriately mitigate requests. ELT Journal, 62(4), 349-357. https://doi.org/10.1093/elt/ccm092

[20] Yazdanfar, S., \& Bonyadi, A. (2016). Request Strategies in Everyday Interactions of Persian and English Speakers. SAGE Open, 6(4), 215824401667947. https://doi.org/10.1177/2158244016679473 